\title{
CONF-911202--46
}

\section{SYNTHESIS OF RARE-EARTH-BASED OXIDES FOR THE CERAMIC INDUSTRY: FROM LABORATORY TO PILOT PLANT*}

U. Balachandran, S. E. Dorris, M. T. Lanagan, and R. B. Poeppel Materials and Components Technology Division

Argonne National Laboratory

Argonne, IL 60439

ANL/CP- -73621

DE92 006981

and

J. M. Tourre and J. W. Golowski

Fine Inorganic Chemicals Division

Rhone-Poulenc

Cranbury, IJJ 08512

November 1991

The subimitzed manuscript has been authored
by a contractor of the U.S. Government
under contract No. W-31-109ENG.38.
Accordingly, the U. S. Government retains a
nonexclusive. Poyalty-free license to publigh
or reproduce the published form of this
contribution, or allow others to do 0 , for
U.S. Government purposes.

Manuscript to be submitted for publication in the Proceedings of the 1991 Fall Meeting of the Materials Research Society: Symposium on Synthesis and Processing of Ceramics, Boston, MA, December 2-6, 1991.

*Work at ANL is supported by the U.S. Department of Energy, Conservation and Renewable Energy, as part of a program to develop electric power technology, under Contract W-31-109-Eng-38.

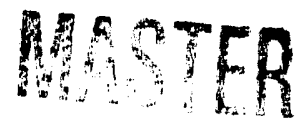


SYNTHESIS OF RARE-EARTH-BASED OXIDES FOR THE CERAMIC INDUSTRY: FROM LABORATORY TO PILOT PLANT

U. Balachandran, S. E. Dorris, M. T. Lanagan, and R. B. Poeppel Materials and Components Technology Division

Argonne National Laboratory

Argonne, IL 60439

and

J. M. Tourre and J. W. Golowski

Fine Inorganic Chemicals Division

Rhone-Poulenc

Cranbury, NJ 08512

\section{ABSTRACT}

A wide variety of compounds, eg., superconductors, chromites, and manganites, have been synthesized by spray drying a mixture of salts or a combination of salts and sols in a flash dryer. The process allows for good control of stoichiometry, morphology, particle size, and surface area. Appropriate particle-growth and synthesis heat treatments of these fine powders were performed. The resultant powders were evaluated for possible applications in fuel cells and superconductors. The processes have been scaled up to a capacity of $\approx 40 \mathrm{Kg}$ a day.

\section{INTRODUCTION}

Interest in rare-earth-based oxides for electronic applications has risen dramatically recently. The rare-earth-related oxides are used in high-temperature ceramic superconductors $\left(\mathrm{YBa}_{2} \mathrm{Cu}_{3} \mathrm{O}_{\mathrm{x}}\right)$, interconnection materials (doped $\mathrm{LaCrO}_{3}$ ), and cathode materials (doped $\mathrm{LaMnO}_{3}$ ) in monolithic solid oxide fuel cells (MSOFC). Most of the research on $\mathrm{YBa}_{2} \mathrm{Cu}_{3} \mathrm{O}_{\mathbf{x}}$ (YBCO) superconductors has been performed on samples prcduced by conventional methods, such as blending stoichiometric amounts of $\mathrm{Y}_{2} \mathrm{O}_{3}, \mathrm{BaCO}_{3}$, and $\mathrm{CuO}$. These solid-state reactions between 
constituent oxides and carbonates require long mixing times and hightemperature calcinations with intermittent grinaings before homogeneity is obtained. The long and extensive procedures contaminate the final oxide and affect its superconducting properties. A low-temperature process that can reduce the calcination time and the contamination from the grinding media and container would be favorable for realizing high critical current densities and transition temperatures.

Monolithic solid oxide fuel cells are presently under development for a variety of practical applications (e.g., advanced space and aerospace power systems and electric utility power generation). The MSOFC is composed of a honeycomb of very small cells, each 1 to $2 \mathrm{~mm}$ in diameter. The walls of the honeycomb are formed from thin $(25$ to $100 \mu \mathrm{m})$ ceramic layers of four cell components [1,2]. The material currently used for MSOFC cathode is $\mathrm{Sr}$-doped $\mathrm{LaMnO}_{3}$. The rnost satisfactory results to date are obtained when two $\mathrm{Sr}$-doped $\mathrm{LaMnO}_{3}$ powders with differing sinterabilities are used. From the fabrication point of view, it will be advantageous to use one type of powder with desired sinterability. In the MSOFC configuration, adjacent small cells are electrically connected via an interconnection (bipolar) layer. The development of the interconnect for the MSOFC has posed a significant material development challenge because of the particularly demanding set of electrical, mechanical, and chemical requirements for this component. Previous work has identified an acceptor ( $\mathrm{Mg}$ or $\mathrm{Sr}$ )-doped $\mathrm{LaCrO}_{3}$ as a suitable material, except for the fact that $\mathrm{LaCrO}_{3}$, like all $\mathrm{Cr}$-containing oxides, will not sinter to high densities in air. The reason for the low sinterability in these materials is that the predominant mode of mass transport during firing is an evaporation-condensation mechanism which leads to coarsening of the original particles without densification. To obtain high densities, it is necessary to sinter $\mathrm{LaCrO}_{3}$ to temperatures in excess of $1700^{\circ} \mathrm{C}$ in a reducing atmosphere $[3,4]$. However, these conditions are unacceptable for fabrication of the MSOFC for two reasons. One reason is that the interdiffusion of the cell components will become significant at such high temperatures. The other is that the $\mathrm{LaMnO}_{3}$ will decompose to $\mathrm{La}_{2} \mathrm{O}_{3}$ and $\mathrm{MnO}$ in reducing atmospheres. Given the favorable properties of $\mathrm{LaCrO}_{3}$ (thermal eapansion characteristics, electrical conductivity, and chemical 
stahility), efforts have been concentrated on developing methods of sintering the material at temperatures below $1400^{\circ} \mathrm{C}$ in a relatively oxivizing atmosphere. The approach is to synthesize reactive $\mathrm{LaCrO}_{3}$ powder by a various wet-chemical route [5]. Owing to considerable technological interest in the oxide materials discussed here, it is clear that considerable research must be devoted to the synthesis of these compounds to improve the physical and chemical characteristics of the powders.

\section{EXPERIMENTAL}

During its investigation of the synthesis of fine inorganic compounds for the ceramic industry, Rhone-Poluenc reviewed all the processes [6-9] for both chemical and chemical-engineering points of view. Coprecipitation, although attractive for certain applications mostly in the catalysis field, was found to be difficult to control, and extrapolation was a major concern. Furthermore, for each new compound, a study would be needed to control the mixing-nucleation characteristics of the new system. Sol-gel synthesis was found to be too expensive, and classical atomization did not meet the requirements for chemical homogeneity.

To meet the need of the market, Rhone-Poluenc developed a process that is a compromise between classical atomization and the aerosol reactor. The first step in this process is an atomization of a mixture of salts or a combination of salts and sols. A patented spray dryer which operates at higher inlet temperatures (above $700^{\circ} \mathrm{C}$ ) and higher outlet temperature (above $250^{\circ} \mathrm{C}$ ) than classical dryers is used. The system is co-current, with a very short residence times. For the same evaporation capacity, the unit would be smaller than a classical spray dryer. Therefore, the temperature profile in the dryer is very homogeneous. The dryer is an almost perfectly plug-flow reactor, which insures a homogeneous treatment of the particles. The droplet sizes are generated by a two-fluid nozzle, the main advantage of which is that the atomization is made by the hot gases. The dryer design allows for a very fast and homogeneous treatment. As for the classical dryer, the parameters are set to avoid the explosion of the droplets. This process is 
simple and can be adapted to many compounds, such as $\mathrm{BaTiO}_{3}, \mathrm{YBCO}$, yttria-stabilized $\mathrm{ZrO}_{2}$, bismuth-based superconductors, doped chromites and manganites.

The selection of a sol or a salt depends on the compounds (decomposition temperature or melting point of the salts used). It also depends on the morphology and physical properties that are desired in order to obtain a ceramic with an adequate microstructure. Chemical processes allow the control of the size of the colloids, therefore giving a great flexibility to the process. Figure 1 describes the process as applied to the synthesis of YBCO superconductor. A pilot plant unit (capacity up to 8 Ton a year) has been built. Table 1 summarizes the characteristics of the different YBCO grades produced today. As can be seen, the process allows the control of particle size from $0.5 \mu \mathrm{m}$ up to a few $\mu \mathrm{m}$. Highly phase pure YBCO (Figure 2) can be produced with a level of impurity phases below the detection level of X-ray diffraction. The calcined product is agglomerated, but a jet milling step is enough to produce submicron particles. Any specific composition can be produced; dopants can also be easily incorporated into the composition. A rotary calciner, with a ceramic tube, allows homogeneous calcination. The degree of stoichiometric homogeneity has been found to be around 1 cubic micron when using nitrates. Better homogeneity can be obtained by using different salts. The major advantages of the method, in addition to its flexibility, are the ability to use inorganic compounds in aqueous media and the fact that the raw materials used (nitrates) are not very expensive.

With slight modification of the process, we produced large size batches of Sr-doped $\mathrm{LaCrO}_{3}$ and $\mathrm{Sr}$-doped $\mathrm{LaMnO}_{3}$. The surface areas of these powders varied in the range $2-6 \mathrm{~m}^{2} / \mathrm{g}$, and processing conditions are optimized to produce powders with any desired size and surface area. These powders are then characterized and evaluated for practical applications.

RESULTS AND DISCUSSIONS

YBCO superconductor powders 
The synthesis of YBCO car be achieved by different routes. They can be classified in terms of quality, flexibility, and cost. Almost all of the wetchemical processes lead to a precursor that must be calcined at temperatures above $850^{\circ} \mathrm{C}$ to obtain the orthorhombic phase. The powder synthesized by the present method, on the other hand, is phase-pure orthorhombic in the as-synthesized condition [see Fig. 2]. Enothermic or exothermic reactions or melting events associated with impurity phases were identified by differential thermal analysis (DTA) [10]. For the RhonePoluenc powder, the only event observed was an onset of melting at $\approx 1020^{\circ} \mathrm{C}$ due to incongruent melting of YBCO [Fig. 3, curve (a)]. Conventionally processed powder exhibited an endotherm at $\approx 920^{\circ} \mathrm{C}$, caused by melting of a CuO- $\mathrm{BaCuO}_{2}$ eutectic $[11,12,13]$, in addtion to the endotherm with onset at $\approx 1020^{\circ} \mathrm{C}$ [Fig. 3, curve (b)]. The phase-pure YBCO powder was uniaxially pressed into long bars $(\approx 9 \mathrm{~cm} \times 8 \mathrm{~mm} \times 5.5$ $\mathrm{mm}$ ) and sintered at $\approx 900^{\circ} \mathrm{C}$ for $3 \mathrm{~h}$ in flowing oxygen at a total pressure of $\approx 7.6 \mathrm{~mm} \mathrm{Hg}$ (corresponds to a oxygen partial pressure of $10^{-2} \mathrm{~atm}$.). During cooling, the oxygen pressure was increased and samples were annealed at $\approx 450^{\circ} \mathrm{C}$ for $24 \mathrm{~h}$ in flowing oxygen at arnbient pressure. The density of sintered samples ranged from 93 to $96 \%$ of theoretical value. The transport critical current densities $\left(\mathrm{J}_{\mathrm{C}}\right)$, measured in zero applied magnetic field at $77 \mathrm{~K}$ with a criterion of $1 \mu \mathrm{V} / \mathrm{cm}$ were about $300 \mathrm{~A} / \mathrm{cm}^{2}$. The measured critical currents in these samples were $\approx 150 \mathrm{~A}$.

Furthermore, it was found that these samples are relatively less sensitive to moderate applied magnetic field of $\approx 40 \mathrm{G}$. The $\mathrm{J}_{\mathrm{c}}$ degraded at a rate of $\approx 0.2 \% / G$. For samples made using conventionally processed powders, the value was $\approx 2 \% / G$, i.e., the $J_{c}$ degrades drastically with applied field. Since the microstructures of pressed and sintered pellets are nonuniform and not textured, the limits in $\mathrm{J}_{\mathrm{c}}$ that are inherent in the Rhone-Poluenc powders processed in reduced oxygen pressure condictions have yet to be identified.

\section{Sr-doped $\mathrm{LaCrO}_{3}$}

The $\mathrm{Sr}$-doped $\mathrm{LaCrO}_{3}$, as determined by X-ray diffraction, was found to be phase-pure percyskite structure. The surface area of the powder was $\approx 3.7 \mathrm{~m}^{2} / \mathrm{g}$ and particle size $\approx 0.4 \mu \mathrm{m}$. The powder was compacted using a pressure of $140 \mathrm{MPa}$ to $=55 \%$ of theoretical density. The 
compacts were sintered in air at $1400^{\circ} \mathrm{C}$ for $1 \mathrm{~h}$. The sintered densities were $\approx 90 \%$ of theoretical with interconnected porosity. For comparison, pellets made using powders derived by amorphous citrate process, pioneered by Pechini [14], showed sintered densities in the range $\approx 70 \%$ of the theoretical value. The interconnect material for use in the MSOFC must have densities $>95 \%$ to block the direct inter-mixing of fuel and oxidant gases. Preliminary results indicate that the density of RhonePoluenc powder compacts can be increased to $\approx 95 \%$ when sintering is carried out at $1550^{\circ} \mathrm{C}$, but this temperature is not suitable for MSOFC application-interdiffusion of cell components is a significant problem at these high temperatures. Work is underway to synthesize the powders with increased reactivity to achieve higher densities suitable for MSOFC applications.

\section{CONCLUSION}

Considerable research has been devoted to the chemical synthesis of oxide powders to improve the physical and chemical characteristics. We have developed a versatile process applicable to a wide variety of oxides. The YBCO superconductor synthesized by the technique described results in pure orthorhombic powder whereas other wet-chemical techniques yield precursors which need to be calcined at high temperatures. Coprecipitation and classical atomization will have difficulty to maintain a high degree of homogeneity during scale-up. For aerosol processes, the current yields are too low and there is a major concern related to the solid-gas separation system. The Rhone-Poluenc process, by combining the simplicity of the classical atomization with some of the advantages of aerosol processes, is a good cost/quality compromise, which today produces powder in pilot plant quantities. The $\mathrm{Sr}$-doped $\mathrm{LaCrO}_{3}$ shows considerable improvement over the powder synthesized by the amorphous citrate route. Processing modifications are currently underway in further improving the powder characteristics for use in MSOFC applications.

\section{ACKNOWLEDGMENT}


Work at ANL was supported by the U.S. Department of Energy, Conservation and Renewable Energy, as part of a program to develop elcctric power technology, under Contract W-31-109-Eng-38.

\section{REFERENCES:}

1. D. C. Fee, R. K. Steuenberg, T. D. Claar, R. B. Poeppel, and J. P. Ackerman, 1983 National Fuel Cell Seminar Abstracts, (Courtesy Associates, Washington, D.C., 1983), p. 74.

2. U. Balachandran, S. E. Dorris, J. J.Picciolo, R. B. Poeppel, C. C. McPheeters, and N. Q. Minh, in Proceedings of the 24th Intersociety Energy Conversion Engineering Conference, Washington, D.C., $\underline{3}, 1541$ (1989).

3. D. B. Meadowcraft, Br. J. Appl. Phys. 2, 1225 (1969).

4. L. Groupp and H. U. Anderson, J. Am. Ceram. Soc. 모, 449 (1976).

5. L. A. Chick, L. R. Pederson, G. D. Maupin, J. L. Bates, L. E. Thomas, and G. J. Exarhos, J. Mater. Sci. Lett. (in press).

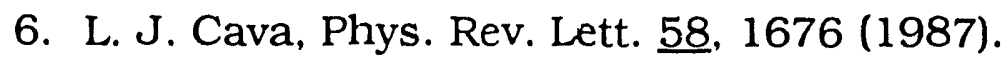

7. R. C. Chiu, W. E. Rhine, R. J. Higgin', and M. J. Cima, in Superconductivity and Ceramic Superconductors II, edited by K. M. Nair, U. Balachandran, Y. M. Chiang, and A. S. Bhalla (The American Ceramic Society, Westerville, OH, 1991), p. 239.

8. ऽ. C. Chen and H. U. Aruderson, Proceedings Industry-University Advanced Materials Conference II, (Adv. Mater. Institute, Golden, CO, 1989) p.520

9. M. J. Cima, R. Chiu, and W. E. Rhine, Mat. Res. Soc. Symp. Proc. $\underline{99}$, 241 (1988). 
10. K. C. Goretta, I. Bloom, N. Chen, G. T. Goudey, M. C. Hash, G. Klassen, M. T. Lanagan, R. B. Poeppel, J. P. Singh, D. Shi, U. Balachandran, J. T. Dusek, and D. W. Capone II, Mater. Lett. Z, 161 (1988).

11. U. Balachandran, R. B. Poeppel, J. E. Emerson, S. A. Johnson, M. T. Lanagan, C. A. Youngdahl, D. Shi, K. C. Goretta, and N. G. Eror, Mater. Lett. 8, 454 (1989).

12. T. Aselage and K. Keefer, J. Mater. Res. $\underline{3}, 1279$ (1988).

13. K. W. Lay and G. M. Renlund, J. Am. Cerm. Soc. ⒊ 1208 (1990).

14. M. P. Pechini, U.S: Patent, 3,330,697 (1967). 


\section{FIGURE CAPTIONS}

Figure 1. Flow chart describing the process as applied to the synthesis of YBCO superconductor.

Figure 2. X-ray diffraction pattern of phase pure YBCO powder.

Figure 3. Differential thermal analysis ? aces of YBCO powder (a) synthesized by the Rhone-Poluenc method and (b) conventional solid-state method. 


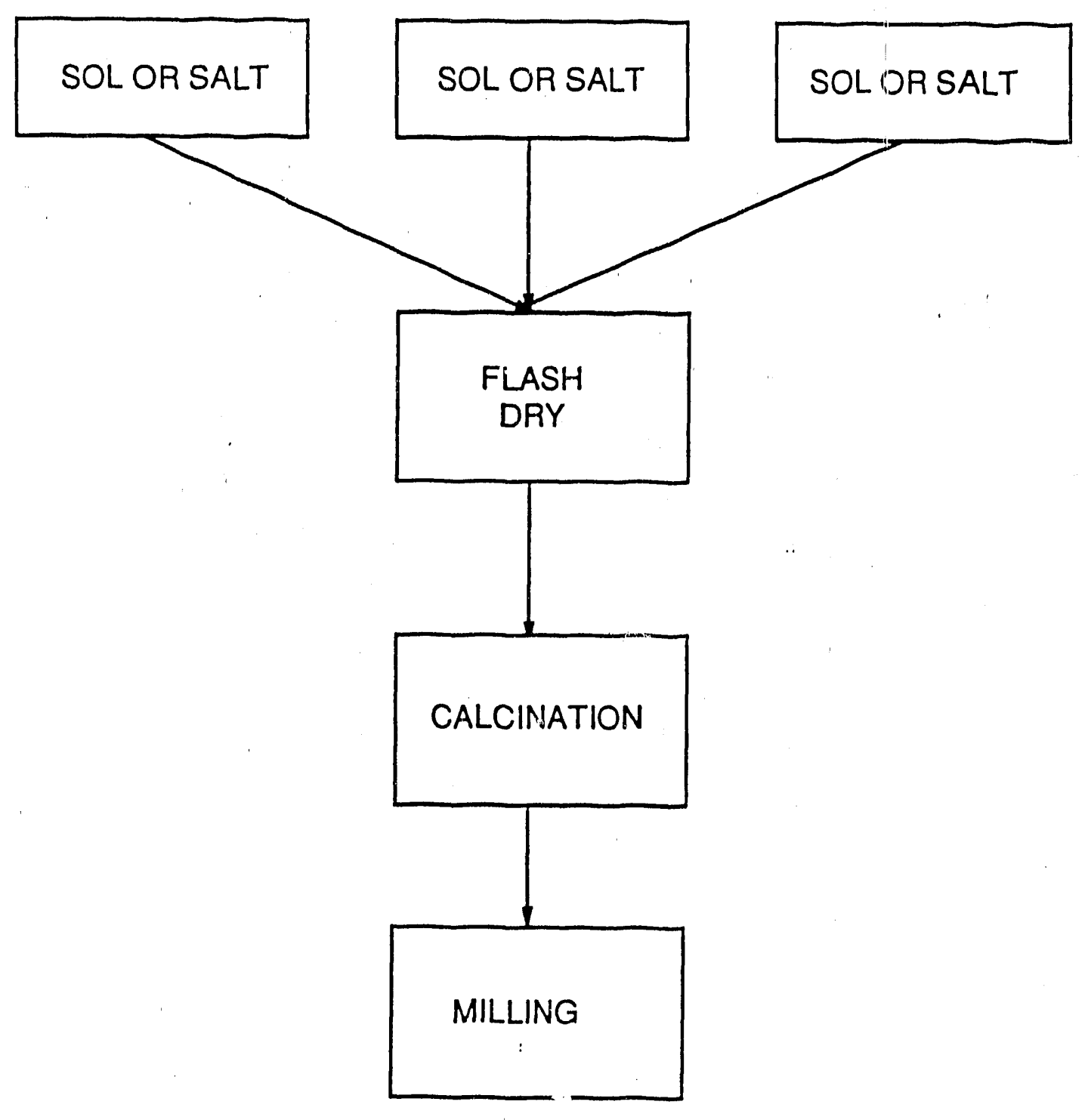




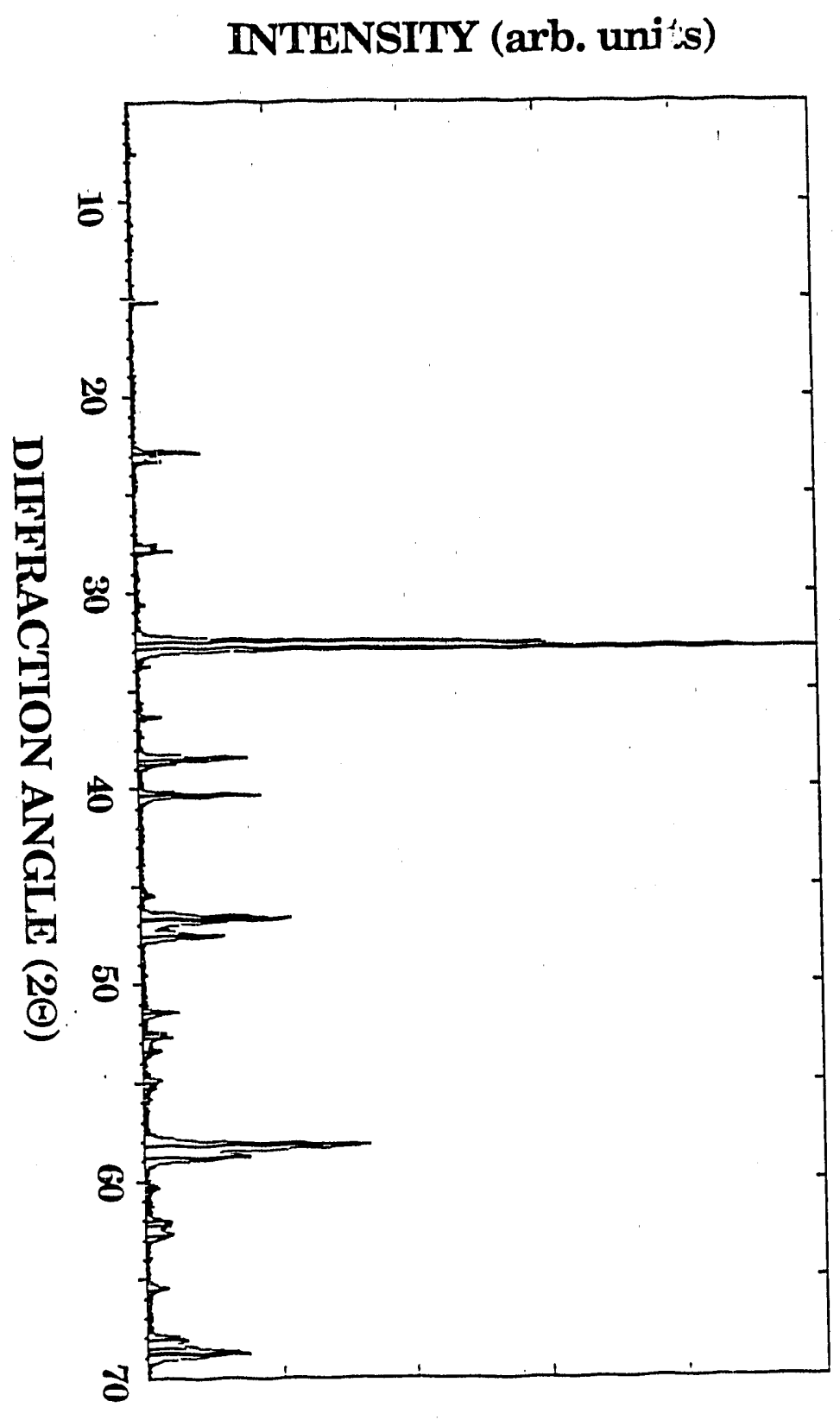




\section{$\Delta H$ (arb. units)}

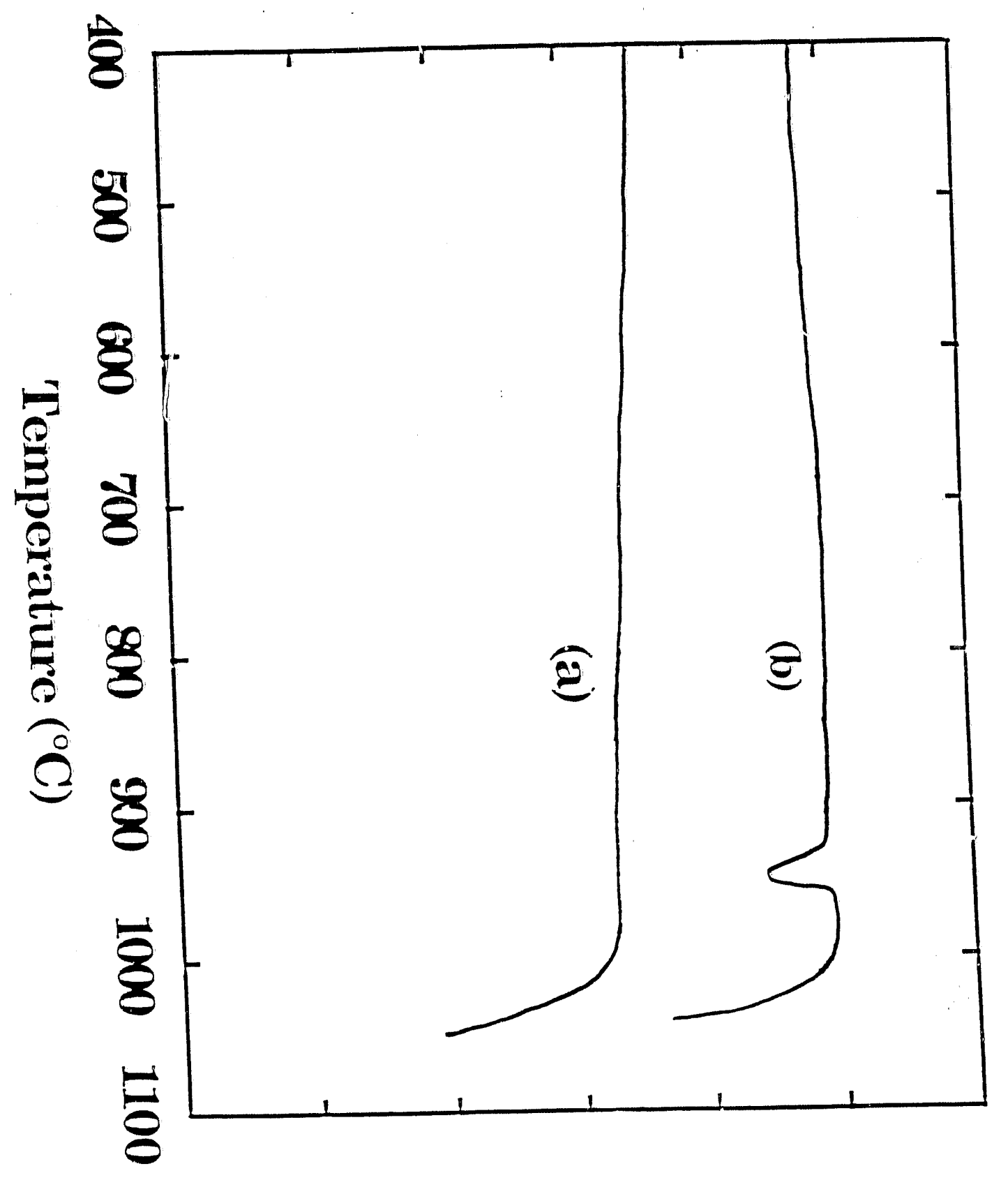




\begin{tabular}{|c|c|c|c|c|c|}
\hline$\sum_{\substack{\infty \\
\vdots}}^{2}$ & $\begin{array}{c}0 \\
0 \\
0 \\
0 \\
j\end{array}$ & $\frac{a}{\frac{2}{n}}$ & $\begin{array}{l}a \\
\infty \\
b\end{array}$ & $\stackrel{\bar{v}}{\bar{v}}$ & 2 \\
\hline 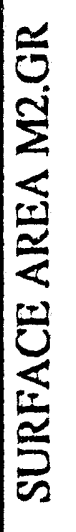 & & n & $\underset{\sim}{\infty}$ & $\ddot{n}$ & $\stackrel{\nabla}{0}$ \\
\hline $\begin{array}{l}\hat{z} \\
\underline{0} \\
\underline{z} \\
z\end{array}$ & 8 & $m$ & $\stackrel{0}{-}$ & ñ & $\ddot{\nabla}$ \\
\hline 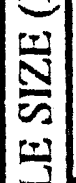 & $\frac{0}{a}$ & ? & $\begin{array}{l}r \\
\check{0} \\
\tilde{0}\end{array}$ & $\ddot{0}$ & $\ddot{q}$ \\
\hline $\begin{array}{l}\bar{\Xi} \\
\approx \\
\approx \\
\approx\end{array}$ & : & ? & $\ddot{0}$ & $\stackrel{n}{n}$ & ri \\
\hline$\frac{\mathfrak{Q}}{\grave{\delta}}$ & & 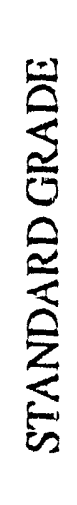 & 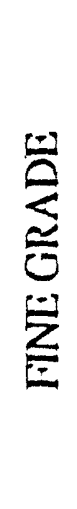 & 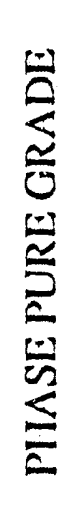 & 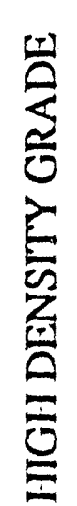 \\
\hline
\end{tabular}



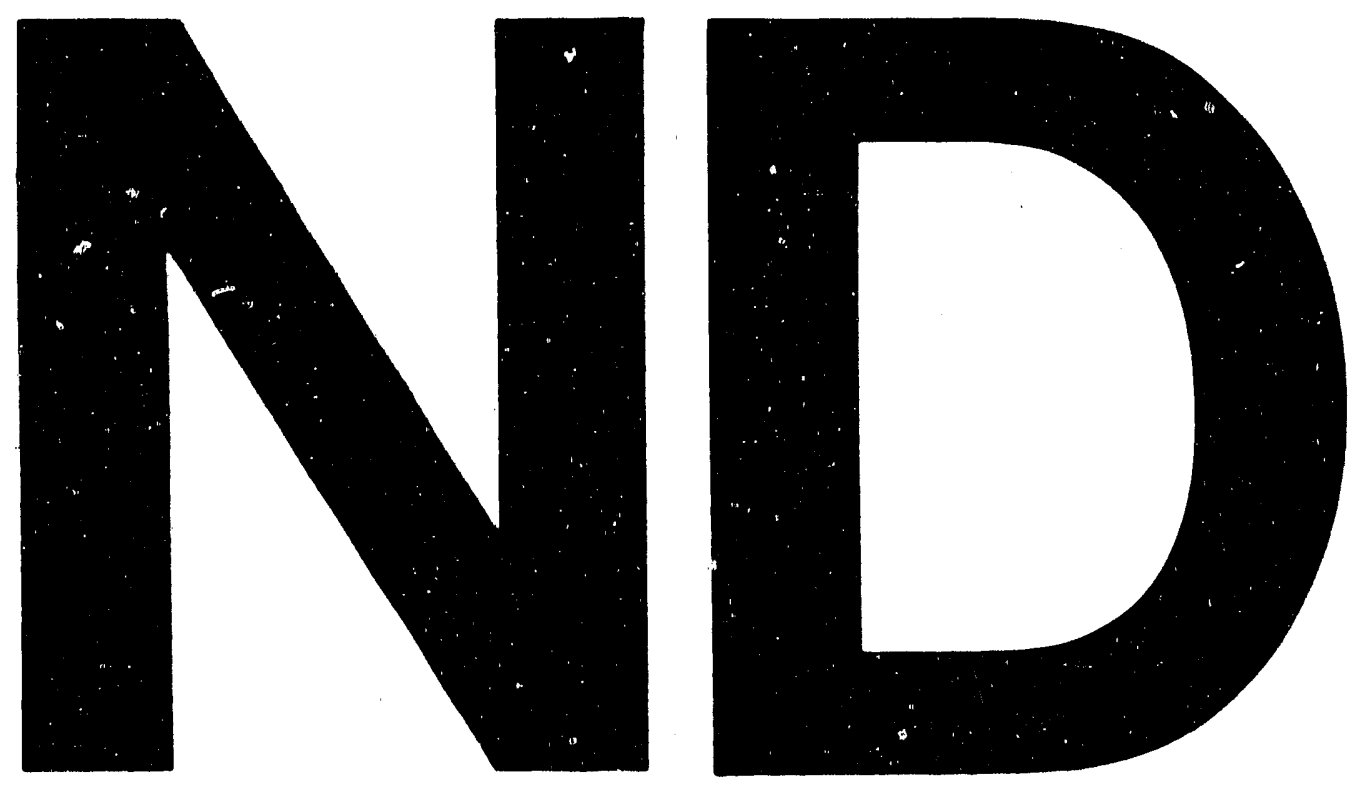

i
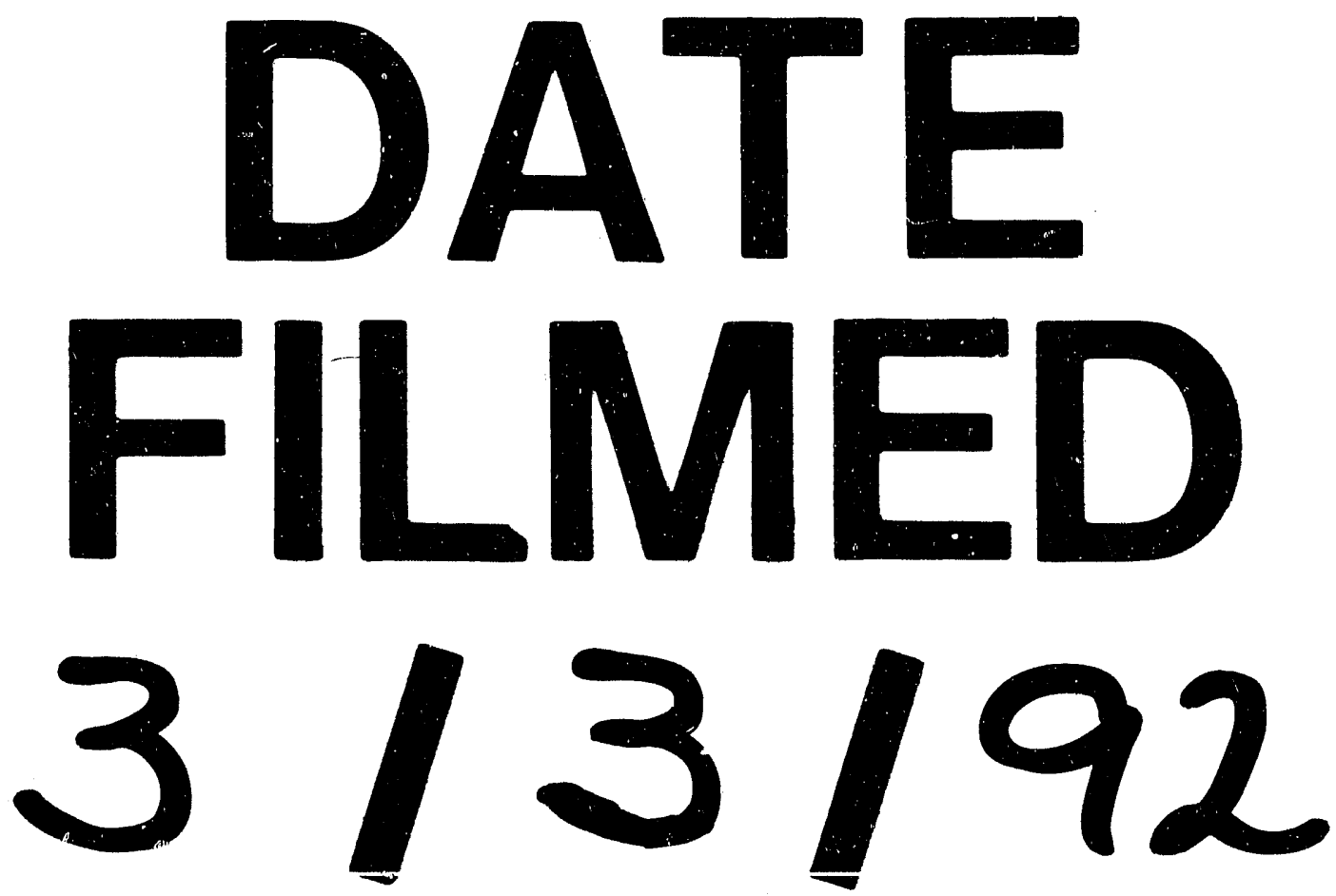
